\title{
Determination of Appropriate Planting Time for Dekoko (Pisum sativum var. abyssinicum) Productivity Improvement in Raya Valley, Northern Ethiopia
}

\author{
Berhane Sibhatu $^{1,}$, , Hayelom Berhe ${ }^{2}$, Gebremeskel Gebrekorkos ${ }^{1}$, Kasaye Abera ${ }^{1}$ \\ ${ }^{1}$ Department of Agronomy, Ethiopian Institute of Agricultural Research, Mehoni Agricultural Research Center, Maichew, Ethiopia \\ ${ }^{2}$ Land and Water Research Process, Ethiopian Institute of Agricultural Research, Mehoni Agricultural Research Center, Maichew, Ethiopia
}

Email address:

berhane76@gmail.com (B. Sibhatu), hayelomberhe631@yahoo.co.uk (H. Berhe), gebremeskel12@gmail.com (G. Gebrekorkos), kasayeab123@gmail.com (K. Abera)

${ }^{*}$ Corresponding author

\section{To cite this article:}

Berhane Sibhatu, Hayelom Berhe, Gebremeskel Gebrekorkos, Kasaye Abera. Determination of Appropriate Planting Time for Dekoko (Pisum sativum var. abyssinicum) Productivity Improvement in Raya Valley, Northern Ethiopia. Agriculture, Forestry and Fisheries. Vol. 5, No. 3, 2016, pp. 43-47. doi: 10.11648/j.aff.20160503.13

Received: April 15, 2016; Accepted: April 22, 2016; Published: June 4, 2016

\begin{abstract}
Dekoko is highly appreciated by the local people for its taste and high market value. However, productivity of Dekoko is limited by improper planting time. An experiment on Dekoko planting time was, therefore, conducted in 2013 and 2014 cropping seasons to determine the appropriate planting time of Dekoko that maximizes its productivity under rain fed conditions. Treatments comprised combinations of four planting time (dry planting about 5-7 days before the beginning of main rain season, when the rain fall amount received greater or equal to $10 \mathrm{~mm}$ at once or cumulative, when the rain fall amount received greater or equal to $20 \mathrm{~mm}$ at once or cumulative and when the rain fall amount received greater or equal to 30 $\mathrm{mm}$ at once or cumulative) were carried out in Randomized Complete Block Design (RCBD) with three replications. The analyzed result showed that days to maturity, number of pods plant ${ }^{-1}$, grain and biomass yields were significantly influenced $(\mathrm{P}<0.05)$ by planting time. Dekoko matured late during dry planting. Dekoko planted when the rain fall amount received is greater or equal to $20 \mathrm{~mm}$ at once or cumulative gave high (21) number of pods plant ${ }^{-1}$. Similarly, the maximum grain (533.53 - $\left.638.00 \mathrm{~kg} \mathrm{ha}^{-1}\right)$ and biomass $\left(1635.23-1820.06 \mathrm{~kg} \mathrm{ha}^{-1}\right)$ yields were produced during planting time when the rain fall amount received is greater or equal to $20 \mathrm{~mm}$ at once or cumulative, while the minimum values were due to dry planting. It is, therefore, concluded that planting of Dekoko when the rain fall amount received is greater or equal to $20 \mathrm{~mm}$ at once or cumulative can be recommended for the growers in the study area to improve Dekoko productivity. Moreover, further research works on different varieties along with different soil moisture levels, planting dates and soil types can be a step forward to identify best sustainable technology on the growth and yield improvements of Dekoko.
\end{abstract}

Keywords: Dekoko, Planting Time, Yield, Yield Components

\section{Introduction}

Cool-season food legumes (CSFLs), which are largely produced in Ethiopia, are mainly produced by subsistence farmers and serveas supplementary protein sources and soil fertilityrestorers. Among the CSFLs, a pea variety locally called Dekoko (Pisum sativum var. abyssinicum) is a unique crop developed and cultivated in Ethiopia [1]. It is restricted to highland regions of Ethiopia (South Tigray and North
Wollo) [2].

Dekoko has highly appreciation for its taste and obtains a premium price in local markets compared to field pea or 'Ater' (Pisum sativum var. sativum) [2]. Farmers and consumers call it as the "Dero-Wot of the poor". This may be to express for its good taste and high nutritional value. Most often, the dry seeds of Dekoko are decorticated and split ('split peas') before boiling. According to [3], in Ethiopia the annual consumption per person of field pea including Dekoko seeds is estimated at $6-7 \mathrm{~kg}$. Because of its 
favorable amino acid profile, it can be a suitable complementary protein source for a cereal based diet. Moreover, its early maturation can make it an important crop in areas where the growing season is too short for other cool season food legumes (CSFLs) and yield losses caused by terminal droughts are common [2].

Appropriate planting time has a promising impact in improving the productivity of legumes. The time from sowing to seedling establishment is of considerable importance in crop production as it has major impacts on crop germination, growth, final yield, and post harvest grain quality [4]. Planting time is adjusted with the availability of soil moisture. Soil moisture supply is an important environmental factor controlling germination and seedling establishment [5]. High seed emergence and seedling establishment contribute directly to the crop yield [6].[7] reported that rapid seed emergence along with fast plant growth and early maturity substantially contributes to high chickpea yield under drought conditions. One of the first physiological disorders taking place during seed germination under dry conditions is a decrease in water uptake by the seed due to low water potential of the germination medium. Slow or sporadic germination and emergence generally result in fewer and small plants, which are more vulnerable to different biotic and abiotic stresses [4]. According to [8], lack of adequate soil moisture in the seedbed is a major hindrance to the establishment of chickpea crop. This is because inadequate soil moisture can reduce seed germination, slow down seedling growth and diminish yield in rainfed crops. Thus, soil moisture is important for early seedling emergence. Similarly, [9] reported that high soil moisture make early seedling emergence of chick pea genotypes; the fast emerged seedlings were taller, produced more branches, developed larger leaf areas and accumulated more above ground biomass as well as specific leaf area than the slow emerging genotypes. According to [10], planting dates should be based on the onset of the rainfall of the growing season in each agro-ecology/location. It is advisable to plant early whenever there is enough moisture in the soil to benefit from higher soil fertility present at the beginning of the rainy season and to achieve physiological maturity before the end of the rainy season.

Dry lands experience unreliable and erratic rainfall that is always inadequate for crop germination, growth and development to reach maturity. With adequate soil moisture chickpea germination percentages are reported to be high leading to high crop yields. With low soil moisture regimes as it is in arid and semi arid lands (ASALs), poor crop germination is experienced leading to poor crop stand and hence low crop yields [11].

There is, therefore, need to explore various technologies that can ensure early and uniform crop germination that will enhance optimum crop stand and establishment that will lead in to optimal crop yields in the ASAL environments. Dekoko, which can grow in the ASAL environments, is the most neglected pulse crop in the research area. A research has not yet been done on yield improvement and development of management practices for Dekoko in the study area. As a result of this, its productivity is low because of mainly poor agronomic practices. Hence, this study was aiming to determine the optimum planting time of Dekoko under varying initial amount of rain fall for its productivity improvement.

\section{Materials and Methods}

\subsection{Description of Experimental Area}

The experiment was carried out under rain fed conditions in 2013 and 2014 cropping seasons at Mehoni Agricultural Research Center testing site. It is $678 \mathrm{~km}$ north of Addis Ababa (the capital city of Ethiopia). The area is situated at an altitude of 1578 meter above sea level (m.a.s.l) having a mean annual rainfall of $750 \mathrm{~mm}$ and its average minimum and maximum annual temperature is $18^{\circ} \mathrm{C}$ and $25^{\circ} \mathrm{C}$, respectively. It lies at latitudes of $12^{\circ} 41^{\prime} 50^{\prime \prime} \mathrm{N}$ and longitudes of $39^{\circ} 42^{\prime} 08^{\prime \prime}$ E. The textural class of the soil is Clay loam with a $\mathrm{pH}$ value of 7.9 [12].

\subsection{Field Experimental Design and Procedures}

The experiment was consisting of four treatments of planting dates. The treatments included dry planting about 57 days before the beginning of main rain season, when the rain fall amount received greater or equal to $10 \mathrm{~mm}$ at once or cumulative, when the rain fall amount received greater or equal to $20 \mathrm{~mm}$ at once or cumulative, when the rain fall amount received greater or equal to $30 \mathrm{~mm}$ at once or cumulative. The amount of rain fall was measured in the metrological station of the research site. The treatments were arranged in a randomized completed block design (RCBD) with tree replications having a plot size of $6 \mathrm{~m} \times 5 \mathrm{~m}$. The spacing between blocks and plots was $1.5 \mathrm{~m}$ and $0.5 \mathrm{~m}$, respectively. Urea and Triple super phosphate (TSP) were used as source of $\mathrm{N}$ and $\mathrm{P}$, respectively. Full dose of $\mathrm{P}(20 \mathrm{~kg}$ $\mathrm{P} \mathrm{ha}^{-1}$ ) in the form of $\mathrm{P}_{2} \mathrm{O}_{5}$ was applied at planting as broad casted application method. Similarly, $23 \mathrm{~kg}^{-1}$ of $\mathrm{N}$ was applied as a starter during planting time of each treatment. Local variety of Dekoko was used as a test crop. The other crop management practices like weeding, thinning and chemical spraying were applied uniformly for all plots as per recommendations in field pea.

\subsection{Data Collection and Statistical Analysis}

Data on days to $90 \%$ maturity, plant height $(\mathrm{cm})$, pod number plant ${ }^{-1}$, seed number pod ${ }^{-1}$, grain yield $\left(\mathrm{kg} \mathrm{ha}^{-1}\right)$, biomass yield $\left(\mathrm{kg} \mathrm{ha}^{-1}\right)$ were collected and analyzed. The data were collected from the net harvestable area of $5.5 \mathrm{~m}$ by 4.5 $\mathrm{m}$. Five plants from the net plot area were pre tagged to collect data of plant height, pod number plant ${ }^{-1}$ and three pods per each of these plants with a total of fifteen pods were considered to determine seed number pod $^{-1}$. Dry matter was measured using electronic sensitive balance after the net plot area plants had been harvested and oven dried at $70^{\circ} \mathrm{C}$ till constant dry weight was attained. Similarly, shelled seed 
yield was taken at $10.5 \%$ adjusted moisture level using electronic sensitive balance from the harvested plants of net plot area.

The collected variables were subjected to the analysis of variance using the SAS software version 9.1 [13] and significance difference among the treatment means was computed with least significant difference (LSD) at 5\% probability level as cited in [14].

\section{Results and Discussion}

\subsection{Days to $90 \%$ Physiological Maturity}

Days to $90 \%$ physiological maturity was significantly influenced due to planting time in both cropping seasons (Table 1). Dry planting of Dekoko took more time (86.67 days) than the others. It was significantly superior $(\mathrm{P}<0.05)$ to the others. The other treatments were significantly similar to each other. Time taken to maturity was remarkably prolonged with a decline of soil moisture content. In other words, it has been noted that on leaving the sown seeds for a considerable period at low soil moisture content, the time to emergence becomes maximally prolonged which in turn results delay of maturity. This finding was in agreement with the findings of [9] who noted that emergence of chick pea genotypes was significantly influenced due to soil moisture at which low soil moisture prolonged seedling emergence.

Table 1. Effect of planting time on mean values of days to $90 \%$ maturity and plant height of Dekoko.

\begin{tabular}{lllllll}
\hline \multirow{2}{*}{ Treatments } & \multicolumn{3}{l}{ Days to 90\% Maturity } & \multicolumn{3}{c}{ Plant height (cm) } \\
\cline { 2 - 7 } & $\mathbf{2 0 1 3}$ & $\mathbf{2 0 1 4}$ & Mean & $\mathbf{2 0 1 3}$ & $\mathbf{2 0 1 4}$ & Mean \\
\hline $\begin{array}{l}\text { Dry planting } \\
\text { When rain fall } \geq 10\end{array}$ & $86.67 \mathrm{a}$ & $85.67 \mathrm{a}$ & 86.17 & 41.33 & 56.67 & 49.00 \\
mm & $81.33 \mathrm{~b}$ & $82.00 \mathrm{~b}$ & 81.67 & 36.67 & 61.67 & 49.17 \\
$\begin{array}{l}\text { When rain fall } \geq 20 \\
\text { mm }\end{array}$ & $81.33 \mathrm{~b}$ & $82.00 \mathrm{~b}$ & 81.67 & 36.33 & 63.00 & 49.67 \\
When rain fall $\geq 30$ & & & & & & \\
mm & $80.67 \mathrm{~b}$ & $81.67 \mathrm{~b}$ & 81.17 & 39.00 & 62.33 & 50.67 \\
CV (\%) & 2.58 & 1.75 & & 12.93 & 6.03 & \\
LSD (0.05) & 4.25 & 2.90 & & NS & NS & \\
\hline
\end{tabular}

Means with the same letter (s) in the same column are not significantly different at $\mathrm{P}<0.05 ; \mathrm{NS}=$ Non-significant; $\mathrm{LSD}=$ least significant difference; $\mathrm{CV}=$ Coefficient of variance

\subsection{Plant Height}

According to Table 1, plant height was not significantly affected by planting time in both cropping seasons. Generally, the plant height was ranged from $49 \mathrm{~cm}$ to $51 \mathrm{~cm}$. However, plant height significantly differed $(\mathrm{P}<0.05)$ due to soil moisture difference at planting time at which the shortest plant height of pea was obtained under limited soil moisture content [9]. Moreover, a substantial reduction in soybean plant height as a result of a short period of water stress has been reported by [15].

\subsection{Number of Pods Plant ${ }^{1}$}

Concerning to pods plant ${ }^{-1}$, it was significantly influenced
$(\mathrm{P}<0.05)$ due planting time in both cropping seasons. In 2013 cropping season, the highest number of pods plant ${ }^{-1}$ (20.67) was obtained from the time of Dekoko planting when the rain fall amount received is greater or equal to $20 \mathrm{~mm}$ at once or cumulative, and it was statistically at par with the other treatments excluding dry planting. However, the lowest number of pods plant ${ }^{-1}$ (17.00) was gained when Dekoko was planted at dry condition. similarly, in 2014 cropping season, the highest value (21.33) was obtained from the time of Dekoko planting when the rain fall amount received is greater or equal to $30 \mathrm{~mm}$ at once or cumulative, and it was statistically at par with the other treatments excluding dry planting. Like to 2013, Dekoko planted during dry soil condition, the number of pods plant ${ }^{-1}$ got reduced by $15.61 \%$. This ascribed to the essential of water for the maintenance of the turgidity necessary for cell enlargement and plant growth as well as its major constituent of physiologically active tissue which brings well performance of the plant to produce its yield components [16].

Table 2. Effect of planting time on pod number plant ${ }^{1}$ and seed number pod ${ }^{-1}$ of Dekoko.

\begin{tabular}{|c|c|c|c|c|c|c|}
\hline \multirow{2}{*}{ Treatments } & \multicolumn{3}{|c|}{ Pod number plant ${ }^{-1}$} & \multicolumn{3}{|c|}{ Seed number pod ${ }^{-1}$} \\
\hline & 2013 & 2014 & Mean & 2013 & 2014 & Mean \\
\hline Dry planting & $17.00 \mathrm{~b}$ & $18.00 \mathrm{~b}$ & 17.50 & $3.67 \mathrm{c}$ & 4.33 & 4.00 \\
\hline $\begin{array}{l}\text { When rain } \\
\text { fall } \geq 10 \mathrm{~mm}\end{array}$ & $19.00 \mathrm{ab}$ & 19.67ab & 19.33 & $4.33 b c$ & 4.33 & 4.33 \\
\hline $\begin{array}{l}\text { When rain } \\
\text { fall } \geq 20 \mathrm{~mm}\end{array}$ & $20.67 \mathrm{a}$ & $21.00 \mathrm{a}$ & 20.83 & $5.33 \mathrm{a}$ & 5.33 & 5.33 \\
\hline $\begin{array}{l}\text { When rain } \\
\text { fall } \geq 30 \mathrm{~mm}\end{array}$ & $19.00 \mathrm{ab}$ & $21.33 \mathrm{a}$ & 20.17 & $4.67 \mathrm{ab}$ & 4.67 & 4.67 \\
\hline $\mathrm{CV}(\%)$ & 5.50 & 5.34 & & 9.80 & 18.56 & \\
\hline $\operatorname{LSD}(0.05)$ & 2.08 & 2.13 & & 0.88 & NS & \\
\hline
\end{tabular}

Means with the same letter (s) in the same column are not significantly different at $\mathrm{P}<0.05 ; \mathrm{NS}=$ Non-significant; $\mathrm{LSD}=$ least significant difference; $\mathrm{CV}=$ Coefficient of variance

\subsection{Number of Seeds Pod $^{1}$}

Planting time caused significant effect on the number of seeds pod ${ }^{-1}$ of Dekoko in 2013 cropping season. Based on this result, the highest number of seeds pod ${ }^{-1}$ (5.33) was recorded from the time of planting when the rain fall amount received is greater or equal to $20 \mathrm{~mm}$ at once or cumulative, and it was statistically similar with the time of planting when the rain fall amount received is greater or equal to $30 \mathrm{~mm}$ at once or cumulative. On the other hand, the lowest number of seeds $\operatorname{pod}^{-1}$ (3.67) was recorded due to dry planting. This might be due to the fact that water is the solvent in which salts, sugars and other solutes move from cell to cell and organ to organ which in turn results in formation of seeds, and water is a reagent in photosynthesis for production of more dry matter and yield. This was confirmed to the report of [16]. In 2014 cropping season, number of seeds pod $^{-1}$ was not significantly varied due to planting time where seeds $\operatorname{pod}^{-1}$ of Dekoko ranged from 4.33 to 5.33 .

\subsection{Grain Yield}

Concerned to grain yield of Dekoko, planting time caused 
significant effect $(\mathrm{P}<0.05)$ on it in both cropping seasons. Accordingly, in 2013cropping season, the highest grain yield $\left(533.53 \mathrm{~kg} \mathrm{ha}^{-1}\right)$ was obtained during planting time when the rain fall amount received is greater or equal to $20 \mathrm{~mm}$ at once or cumulative, and unlike to dry planting, it was statistically at par with the other treatments (Table 3). Nevertheless, the lowest grain yield (448.47 $\mathrm{kg} \mathrm{ha}^{-1}$ ) was gained due to dry planting. A similar trend was occurred in 2014 cropping season where the highest value $\left(638.00 \mathrm{~kg} \mathrm{ha}^{-1}\right)$ was recorded when the rain fall amount received is greater or equal to 20 $\mathrm{mm}$ at once or cumulative, while the lowest (545.33 $\left.\mathrm{kg} \mathrm{ha}^{-1}\right)$ was obtained due to dry planting of Dekoko (Table 3 ). This was attributed to the role of moisture in early vegetative growth and enhancing leaf area which in turn results in accumulation of more yields. This confirmed to the previous findings of [7] that showed that rapid seedling growth has been found to be associated with well established seedling and subsequent early growth in chickpea which in turn contributes favorably to high yield under drought conditions. Likewise, [17] reported that reduced soil moisture during the early seedling stage diminishes leaf growth which in turn would result in a reduction of both dry matter and yield.

Table 3. Mean values of grain and biomass yields of Dekoko as influenced by planting time.

\begin{tabular}{|c|c|c|c|c|c|c|}
\hline \multirow{2}{*}{ Treatments } & \multicolumn{3}{|c|}{ Grain yield $\left(\mathrm{kg} \mathrm{ha}^{-1}\right)$} & \multicolumn{3}{|c|}{ Biomass yield $\left(\mathrm{kg} \mathrm{ha}^{-1}\right)$} \\
\hline & 2013 & 2014 & Mean & 2013 & 2014 & Mean \\
\hline Dry planting & $448.47 b$ & $545.33 b$ & 496.90 & $1386.78 b$ & $1428.95 b$ & 1407.86 \\
\hline When rain fall $\geq 10 \mathrm{~mm}$ & $493.02 \mathrm{ab}$ & $563.33 b$ & 528.18 & $1496.60 \mathrm{ab}$ & $1580.22 \mathrm{ab}$ & 1538.41 \\
\hline When rain fall $\geq 20 \mathrm{~mm}$ & $533.53 \mathrm{a}$ & $638.00 \mathrm{a}$ & 585.77 & $1635.23 \mathrm{a}$ & $1820.06 \mathrm{a}$ & 1727.65 \\
\hline When rain fall $\geq 30 \mathrm{~mm}$ & $518.31 \mathrm{a}$ & $600.33 \mathrm{ab}$ & 559.33 & $1536.97 \mathrm{ab}$ & $1730.78 \mathrm{a}$ & 1633.87 \\
\hline $\mathrm{CV}(\%)$ & 5.41 & 5.08 & & 5.26 & 7.85 & \\
\hline $\operatorname{LSD}(0.05)$ & 53.83 & 59.56 & & 159.04 & 257.17 & \\
\hline
\end{tabular}

Means with the same letter (s) in the same column are not significantly different at $\mathrm{P}<0.05$; LSD $=$ least significant difference; $\mathrm{CV}=$ coefficient of variance

\subsection{Biomass Yield}

Referring to Table 3 , the treatments exhibited substantial variations for biomass yield. In 2013, the highest biomass yield (1635.23 $\mathrm{kg} \mathrm{ha}^{-1}$ ) was produced during planting time when the rain fall amount received is greater or equal to $20 \mathrm{~mm}$ at once or cumulative, and unlike to dry planting, it was statistically at par with the other treatments. It gave $17.92 \%$ more biomass yield than dry planting at which the lowest result was obtained. Correspondingly, in 2014, the maximum biomass $(1820.06 \mathrm{~kg}$ $\mathrm{ha}^{-1}$ ) was produced during planting time when the rain fall amount received is greater or equal to $20 \mathrm{~mm}$ at once or cumulative (Table 3). Nevertheless, the lowest value was obtained due to dry planting which was $21.49 \%$ lower than the maximum biomass yield. This could be due to soil moisture stress during seedling emergence which retarded vegetative growth of the plant. This result is consistent with the work of [9] who reported who reported that biological yield of chick peas was significantly influenced due to soil moisture at which low soil moisture declined the yield. Similar findings have been also reported by [11] who demonstrated that water deficit decreased dry matter accumulation (biological yield) and grain yield per unit area of chick pea.

\section{Conclusions}

Appropriate agronomic management of Dekoko improved its productivity. Identifying optimum planting time is one of the agronomic practices that enhanced Dekoko yield and yield related traits. Accordingly, the findings of this experiment showed that number of pods plant ${ }^{-1}$, grain and biomass yields were significantly affected by planting time of Dekoko. The highest pods plant ${ }^{-1}$ was obtained during planting time when the rain fall amount received is greater or equal to $20 \mathrm{~mm}$ at once or cumulative. Moreover, the maximum grain and biomass yields were produced during planting time when the rain fall amount received is greater or equal to $20 \mathrm{~mm}$ at once or cumulative in both cropping seasons. However, the lowest values of these variables were recorded due to dry planting. Generally, early planting is advisable whenever there is enough moisture in the soil to achieve physiological maturity before the end of the rainy season. It is, therefore, concluded that planting time of when the rain fall amount received is greater or equal to $20 \mathrm{~mm}$ at once or cumulative can be recommended for the growers in the study area to improve Dekoko productivity. Moreover, it can recommend from the findings that further investigation on different varieties along with different soil moisture levels, planting dates, soil types and Integrated Pest Management (IPM) techniques can be a step forward to identify best sustainable technology on the growth and yield improvements of Dekoko.

\section{Acknowledgements}

The authors are thankful to Ethiopian Institute of Agricultural Research (EIAR) for funding this research project. The authors are also sincerely acknowledging the Mehoni Agricultural Research Center for providing all farm facilities.

\section{References}

[1] Haddis, Y., Hussein, M., Berhanu, A., Birhanu, A. "Association of traits with yield in Dekoko (Pisum sativum var. abyssinicum) accessions in the highlands of southern Tigray, Ethiopia." African Journal of Agricultural Research, 10(12): 1480-1487, 19 March 2015.

[2] Yemane, A., and Skjelvag, A. O. "The physic-chemical features of Dekoko (Pisum sativum var. abyssinicum) seeds." J. Agron and Crop Sci., 189: 14-22, 2002. 
[3] Sentayehu, A. "Assessment of Nutrient Contents of Different Field Pea Genotypes (Pisium sativumL.) in South west Ethiopia." Department of Plant Sciences, Jima University, Jimma, Ethiopia, 2009.

[4] Harris, D., Breese, W. A., and Kumar Rao, J. V. D. K. "The improvement of crop yield in marginal environment using "On farm" seed priming: Nodulation, nitrogen fixation and disease resistance." Australian Journal of Agronomy, 56 (11): 1211-1218, 2005.

[5] Tylor, A. G., Motes, J. E. and Kirkham, M. B. "Germination and Seedling Growth Characteristics of Three Tomato Species Affected by Water Deficits."Hort. J., 107: 282-285, 1982.

[6] Maiti, R. K. and Moreno-Limon, S. "Seed and Seedling Traits in Bean (Phaseolus vulgaris L.) and Its Relation to Abiotic Stress Resistance." Legume Res., 24 (4): 211-221, 2001.

[7] Gupta, S. N. "Studies on Genetic Variability for Drought Resistance in Chickpea."Seed Res., 25 (1): 19-24, 1985.

[8] Sharma, R. A. "Influence of Drought Stress on the Emergence and Growth of Chickpea Seedlings." International Chickpea Newsletter, 12: 15-16, 1985.

[9] Hosseini, N. M., Siddique, K. H. M., Palta, J. A., and Berger J. "Effect of Soil Moisture Content on Seedling Emergence and Early Growth of Some Chickpea (Cicer arietinum L.) Genotypes." J. Agric. Sci. Technol, 11: 401-411, 2009.

[10] Kidane, G. Dryland Agriculture Production System in Ethiopia. Addis Ababa, Ethiopia: Ethiopian Institute of Agricultural Research, 2015, pp. 116.
[11] Kamithi, K. D., Kibe, A. M. and Wachira, F. "Effect of different initial soil moisture on desi chickpea ICCV 95107 (Cicer arietinum L.) dry matter production and crop growth rate." International Journal of Environmental and Agriculture Research (IJOEAR), 1 (6): 1-10, October 2015.

[12] Haileslassie, G., Haile, A., Wakuma, B., and Kedir, J. "Performance evaluation of hot pepper (Capsicum annum L.) varieties for productivity under irrigation at Raya Valley, Northern, Ethiopia." Basic Research Journal of Agricultural Science and Review, 4 (7): 211-216, July 2015.

[13] SAS (Statistical Analysis System) Institute. SAS User Guides, Version 9.1. North Carolina, USA: SAS Inc. Cary, 2004.

[14] K. A. Gomez and A. A. Gomez. Statistical Procedures for Agricultural Research, $2^{\text {nd }}$ edition. New York. John Viley and Sons Inc., 1984, pp. 121-35.

[15] Momen, N. N., Carlson, R. E., Shaw, R. H. and Arjmend, O. "Moisture Stress Effects on Yield Components of Two Soybean Cultivars." Agro. J., 71: 86-90, 1979.

[16] Kramer. P. J. "Water stress and plant growth."Agron. J. 55: 31$5,1963$.

[17] Constable, G. R. and Hern, A. B. "Agronomic and Physiological Responses of Soybean and Sorghum Crops to Water Deficits. I. Growth, Development and Yield."Aust. J. Plant Physio., 5: 159-167, 1978. 